\title{
Using cool paving materials to improve microclimate of urban areas - Design realization and results of the flisvos project
}

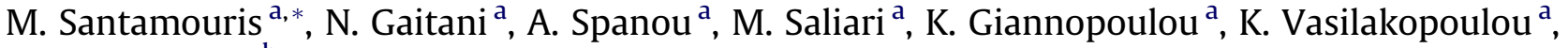 \\ T. Kardomateas ${ }^{b}$ \\ ${ }^{a}$ Group Building Environmental Studies, Physics Department, Univ. Athens, Athens, Greece \\ ${ }^{\mathrm{b}}$ Prefecture of Athens, Athens, Greece
}

\section{A R T I C L E I N F O}

\section{Article history:}

Received 26 December 2011

Received in revised form

27 January 2012

Accepted 28 January 2012

\section{Keywords:}

Heat island

Cool materials and pavements

Heat island mitigation techniques

Urban climatic change

\begin{abstract}
A B S T R A C T
The present paper deals with the application of $4500 \mathrm{~m}^{2}$ of reflective pavements in an urban park in the greater Athens area. The aim was to improve thermal comfort conditions, reduce the intensity of heat island and improve the global environmental quality in the considered area. To our knowledge, this has been the largest application of cool pavements in urban areas in the world. To evaluate the thermal impact of cool paving materials, specific and detailed measurements of the climatic conditions in the park have been performed before and after the installation of the new materials. Validated computerized fluid dynamics techniques have been used to homogenize the boundary conditions occurring during the two experiments and to perform direct comparisons of the climatic quality in the park. It was estimated that the use of cool paving materials contributes to the reduction of the peak ambient temperature during a typical summer day, by up to $1.9 \mathrm{~K}$. At the same time, the surface temperature in the park was decreased by $12 \mathrm{~K}$, while comfort conditions have been improved considerably. It is concluded that the use of reflective paving materials is a very efficient mitigation technique to improve thermal conditions in urban areas.
\end{abstract}

(C) 2012 Elsevier Ltd. All rights reserved.

\section{Introduction}

Urban heat island is the more documented phenomenon of climate change. The specific phenomenon is due to higher urban temperatures compared to the surrounding suburban areas, because of the positive heat balance caused mainly by increased anthropogenic heat, decrease of the air flow, lack of heat sinks and increased absorption of solar radiation by the city structures [1]. Recent research has provided data on the amplitude and characteristics of the heat island phenomenon in many European and US cities [2,3].

Heat island is a very well-studied and documented phenomenon for the city of Athens, Greece. Apart from the global climatic change that causes the ambient temperature and the frequency of heat waves to increase [4-6], heat island is an additional reason that contributes to the temperature rise. The phenomenon is mainly observed in the Central, Western and Southern areas of the city, increasing substantially urban temperatures and making outdoor thermal comfort conditions worse [7-12]. The impact of

\footnotetext{
* Corresponding author.

E-mail addresses: msantam@phys.uoa.gr, sanmat@b-online.gr (M. Santamouris).
}

heat island on the cooling energy consumption of buildings is quite important. Studies have shown that the cooling energy consumption could be doubled because of the increased ambient temperatures in the affected areas [13,14]. At the same time, the environmental quality in the overheated zones is deteriorating as pollution increases [15], and the ecological footprint of the city is seriously growing [16].

To counterbalance the impact of heat island, efficient mitigation techniques have been developed and applied [17]. These techniques include the use of advanced materials for the urban environment, able to amortize, dissipate and reflect heat and solar radiation $[18,19]$, strategic landscaping of cities including appropriate selection and placing of green areas [20,21], use of green roofs [22-25], solar control systems, and dissipation of the excess heat in low temperature environmental heat sinks like the ground, the water and the ambient air [26,27].

Materials presenting a high reflectance to solar radiation together with a high emisivity factor are known as cool materials [28]. Such materials may be used in paths, roads, other urban structures and also in building rooftops, and according to various recent studies they can significantly contribute to the reduction of surface temperatures up to several degrees [29,30]. Numerical modeling has shown that when extended use of reflective materials 
is applied in urban environments, the maximum ambient temperatures may be reduced up to $2{ }^{\circ} \mathrm{C}$, while it has an important impact against global warming [31,32]. Important energy benefits are also associated to the use of reflective materials as the cooling load of buildings is seriously reduced [33,34].

Cool materials may be white materials of very high reflectivity and emissivity [35], or colored materials presenting a high reflectivity to the infrared part of solar radiation together with a high emissivity [36,37]. In parallel, asphaltic materials presenting a much higher reflectivity than conventional asphalt have been developed and are available for use in urban structures, when necessary [38,39]. Apart from the development of highly reflective materials for cities and buildings, advanced materials based on Nano-technological components like thermochromic or PCM doped surfaces have been developed $[40,41]$.

Although highly reflective materials have been extensively tested in cool roof applications, existing data on their potential to mitigate heat islands when used in pavements and other urban structures is very limited. Two applications of cool materials combined to other mitigation techniques to improve the environmental quality of open spaces are already reported for Tirana, Albania and Athens, Greece $[42,43]$. Based on numerical modeling, both studies have shown an important mitigation potential, however, the results are not yet confirmed experimentally.

The present paper reports the results of a real project in Athens, Greece, where extensive use of cool colored paving materials was made, aiming to reduce ambient temperatures during summer and improve the environmental quality of a public urban park. In total, $4500 \mathrm{~m}^{2}$ of cool paving materials have been applied to the area, while extensive measurements combined to numerical modeling have been performed before and after the rehabilitation of the park in order to identify the mitigation potential of the cool materials and document the thermal performance of the whole project.

To our knowledge, it is the first experimentally documented project of urban rehabilitation involving such a large use of cool paving materials.

\section{Description of the site and refurbishment characteristics}

The Flisvos urban park is a coastal area located in the southwestern part of Athens, in the Municipality of Paleo Faliro, and covers a total area close to $80,000 \mathrm{~m}^{2}$, Fig. 1 . On the one side of the park there is a major traffic axis and on the other side there is the sea, Saronic Golf. Flisvos park is currently an area visited by thousands of people and is a major recreation attraction for Southern Athens. During the past years, the specific area was quite degraded because of the prolonged lack of proper maintenance of the park and of the increased criminality during the night time. The park included green areas and paths which led to the sea front. The green part was quite sparsely planted with small trees and bushes. Paved areas were made of asphalt, concrete and dark paving materials. The absorptivity of the paved surfaces was measured between 0.55 and 0.65 , while areas covered with concrete and asphalt presented much higher values 0.79 and 0.89 respectively.

The climate of the area during summer is determined by the heat transferred by the northern winds. The winds are heated traveling over the city and the sea breeze caused by the Saronic Golf. The local microclimate is also significantly influenced by the neighboring highway on the south, which presents very high traffic load. Multiyear measurements of the spatial temperature distribution in the greater Athens area have shown that the particular area presents, together with the Western part of the city, the highest mean monthly air temperatures [44]. Despite the adjacency to the Saronic bay, the southern zones of the city present

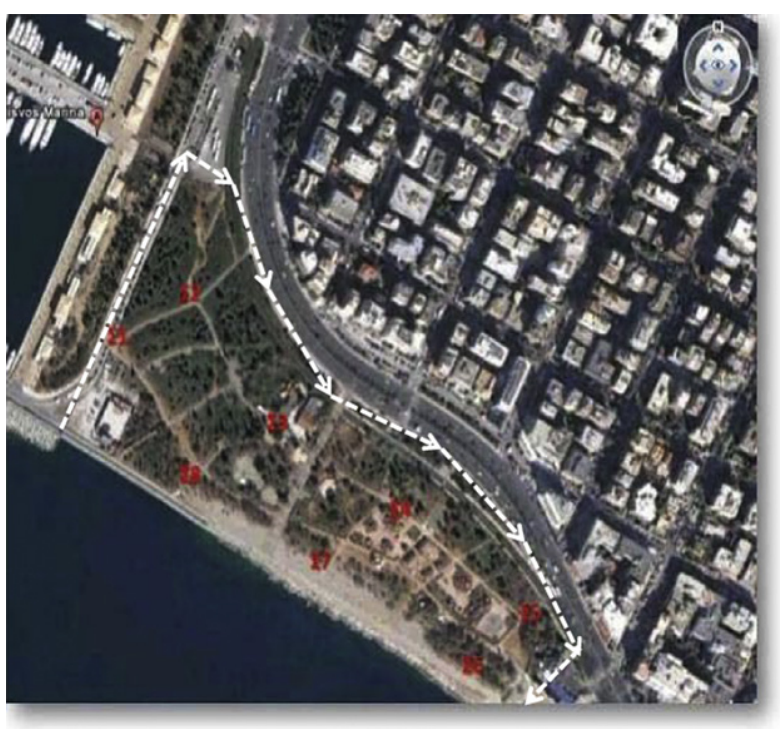

Fig. 1. Satellite picture of the Flisvos Park in Athens

temperatures higher by $1-2 \mathrm{~K}$, in comparison to the northern and north-eastern suburbs.

The local Municipality in collaboration to the Prefecture of Athens has designed and undertaken a major refurbishment plan for the area. The project was implemented in two stages. During the first stage, almost 2500 trees and bushes were planted. At the second stage, almost $4500 \mathrm{~m}^{2}$ of existing pavements were replaced with new cool materials, presenting a high reflectivity to the solar radiation. Detailed information on the optical characteristics of the materials is given in a later section of the paper.

The overall renovation of the park started in 2009 and was finalized during the summer of 2010 . The first stage finished by the end of 2009, while the change of the paving materials took place during June and part of the July of 2010.

The present paper focuses on the second stage and deals with the evaluation of the thermal advantages rising from the use of the cool paving materials.

\section{Characteristics of the selected cool materials}

The paving materials were selected in order to satisfy the following criteria:

a) To present the higher possible non specular reflectivity to solar radiation. However, the use of white materials presenting a reflectivity SR $>0.85$, is highly undesirable as may cause high contrast levels and glare. At the same time, because of the years of use and the deposition of dust and sea salt, high reflectivity values are gradually reduced to values close to $S R=0.5$.

b) To present the lowest possible decrease of the reflectivity because of the aging effects.

c) To present the highest possible emissivity factor, something common for most of the paving materials.

d) To present the highest possible durability and to be aesthetically pleasing.

Based on the above, small concrete blocks of light yellow color were designed and selected. The blocks were colored using infrared reflective pigments mixed in the whole body of the blocks during their manufacture. The dimensions of each concrete block were $20 \mathrm{~cm}$ length, $10 \mathrm{~cm}$ width and $6 \mathrm{~cm}$ height. Almost 50 concrete blocks covered one square meter. 
For esthetic reasons and in order to avoid a rapid degradation of the material's reflectivity, light yellow blocks were selected. The solar reflectivity of the selected blocks was optimized after various tests, which checked different proportions and characteristics of the primary materials, (concrete, sand, gravel, etc), and the infrared reflective pigment. The measured spectral reflectivity of the selected concrete blocks is given in Fig. 2. Measurements were performed in the Materials Lab of the University of Athens, according to the ASTM Standard E903-96 (ASTM E 903 - Standard Test Method for Solar Absorptance, Reflectance, and Transmission of Materials Using Integrating Spheres).

The global solar reflectance of the selected material was calculated close to $60 \%$, while the corresponding reflectivity values in the visible and infrared parts of the spectrum were close to 47 and $71 \%$ respectively. For the calculation of the solar reflectance and the solar reflectance index the ASTM Standard G159-91 Standard was used.

The measurements for the infrared emittance were conducted according to the ASTM Standard E408-71 (ASTM E408-71(1996)) Standard Test Method for Total Normal Emittance of Surfaces. The emissivity of the selected concrete blocks was measured close to 0.9 .

Accelerated aging tests of the selected materials were performed using the Q-Sun Xenon Test Chamber without identifying any significant decrease of the initial reflectivity.

As it concerns the cost of the used cool materials, the actual price in the Greek market is to about $20 \%$ higher than the corresponding conventional materials. It is estimated that a more wide use of these materials will contribute to decrease their cost. A picture of the constructed pavements is given in Fig. 3 .

\section{Evaluation methodology}

Identification of the thermal impact of a specific intervention in uncontrolled environments, like urban open spaces, is not straight forward. Although measurements may be performed before and after the intervention, direct comparisons are not possible as the boundary conditions may be completely different during the experiments.

To evaluate the possible thermal impact of the used cool pavements on the environmental quality of the considered area, the following a specific methodology has been designed and used. The methodology involves five distinct steps.

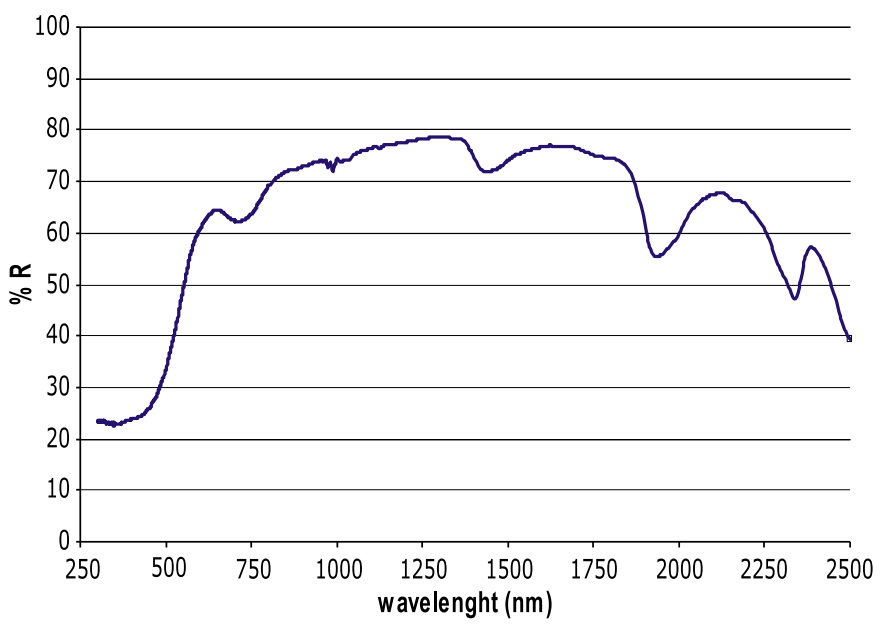

Fig. 2. Spectral reflectivity of the selected paving materials.

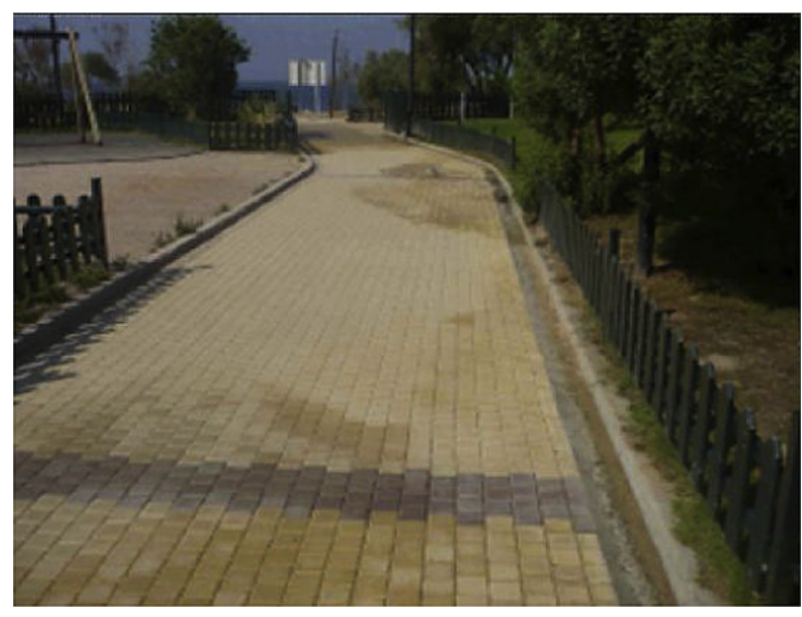

Fig. 3. A picture of the installed paving materials.

\subsection{Step 1. Monitoring of the initial situation}

Detailed measurements of the main climatic parameters in the area including surface and ambient temperatures, wind speed and concentration of pollutants have been performed in the considered area prior to any intervention.

\subsection{Step 2. Development of a computational model for the initial situation}

A thermal model of the area has been created using CFD techniques and simulations have been performed using the boundary conditions measured during the previous step. Comparisons of the measured against the predicted values are performed and the model was improved until a very good agreement is achieved.

\subsection{Step 3. Monitoring of the final situation}

After the installation of the cool pavements, new measurements were carried out. All were performed according to the same experimental protocol described in step 1 .

\subsection{Step 4. Development of a computational model for the final situation}

A new thermal model taking into account the installed cool pavements was created using the same CFD tool. All other parameters and conditions remain the same as in the model described in step 2. Simulations were performed for the boundary conditions measured in step 3 . The calculated values have been extensively compared against the measured ones and the model improved until the best possible agreement is achieved.

\subsection{Step 5. Theoretical comparisons for a typical summer day}

The boundary conditions corresponding to a typical summer day were defined in detail and simulations were performed by using both calibrated thermal models. Values of the main climatic parameters in the considered area have been calculated for the initial and the final situation using exactly the same boundary conditions. Both sets of calculated data have been compared and conclusions on the thermal impact of the cool pavements have been drawn.

Such a methodology offers the possibility to identify in a quite good approximation the possible impact of a major intervention in 
an uncontrolled environment operating under dynamic boundary conditions. Possible errors are associated to the precision of the measuring devices, the knowledge precision of the boundary conditions occurring during the experiments and the accuracy to introduce them in the developed model, the uncertainness about the selection of the proper turbulence model and the computational accuracy of the global numerical model. The methodology is better to be used when the expected impact is quite important and strong. In case the studied phenomena give fine and small differences there is a risk the calculated impact to be in the uncertainty zone of the methodology.

\section{Monitoring strategy}

A complete monitoring plan has been designed and applied for both sets of measurements performed before and after the installation of the cool pavements. Ambient and surface temperatures, relative humidity, wind speed and direction as well as the concentration of suspended particles were recorded during the experiments in many spots in the park.

For the measurements, the mobile urban meteorological station of the University of Athens was used (Fig. 4). The mobile meteorological station consists of: (a) a vehicle and (b) a telescopic mast PT8 Combined Collar Mast Assembly with extended height of $15.3 \mathrm{~m}$, retracted height $3.43 \mathrm{~m}$ and maximum head load $15 \mathrm{~kg}$. Wind speed and direction anemometers and thermometers can be placed on the telescopic mast, at different heights [45]. For the specific experiments, measurements of the ambient temperature and wind speed and direction were performed at a height of $3.5 \mathrm{~m}$.

Circular design thermometers "Vector Instruments type T351PX" were used. The accuracy of the thermometers is $+0.5 \mathrm{~K}$ ( $\mathrm{max}$ ) under normal meteorological conditions. Air temperature was recorded every $30 \mathrm{~s}$.

The mobile station traveled through the whole park, following a specific route. Measurements were performed in a continuous basis; however, eight specific reference points inside the park, shown in Fig. 1, have been selected as references. Measurements at the reference points were recorded on an hourly basis. Comparisons between the various experimental and theoretical data sets have been performed for the reference points.

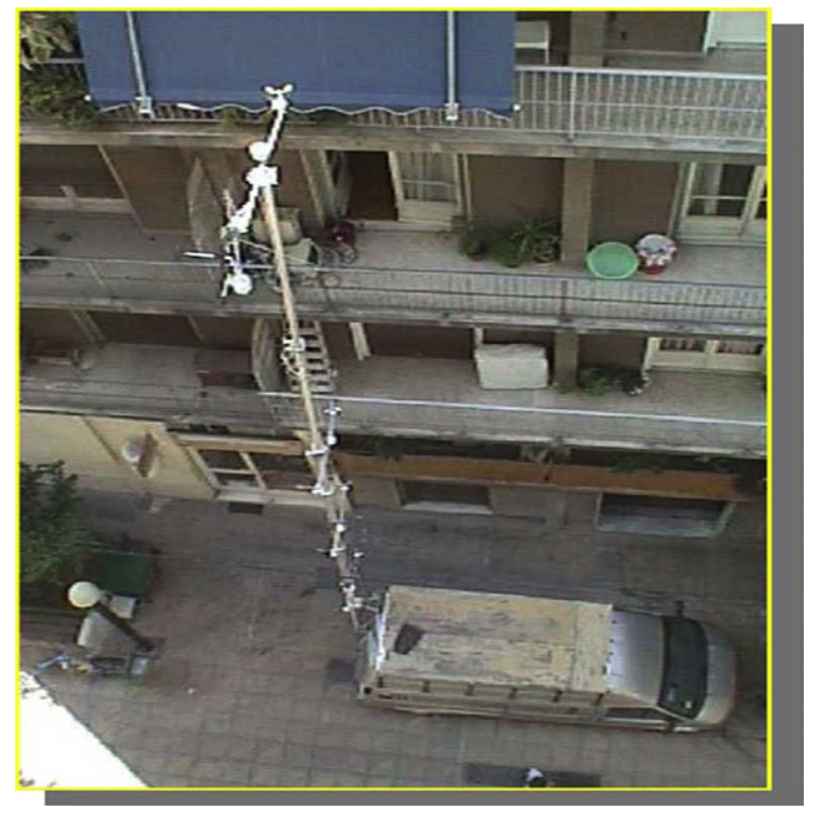

Fig. 4. The mobile meteorological station of the University of Athens.
Parallel to the above measurements, solar radiation data as well as data on the undisturbed wind and temperature were taken from the meteorological station.

\section{The computational thermal model}

Computerized Flow Dynamic Techniques (CFD), were used to evaluate the thermal environment in the considered space. CFD Tools solve the Navier-Stokes equations and provide concrete information on the characteristics of the fluid flow. For the specific project the PHOENICS CFD package was used [46]. As it concerns turbulence, the standard $k-e$ model was used. The values of the surface temperatures were calculated through the TRNSYS [47], simulation tool and then introduced as a boundary to PHOENICS, where simulations of the ambient temperature and wind speed distributions were performed. At the inflow boundaries, the wind field is specified.

In order to take into consideration the global impact of the surrounding space, the park and the neighboring blocks were studied as a whole. The entire area was provided as a solid geometry file (STL), including all the buildings and surrounding areas. A Cartesian grid was adopted.

The dimensions of the grid in the domain of calculations are $1180(x) \times 1314(y) \times 150(z) \mathrm{m}$ and consists of $200 \times 100 \times 15$ cells at each axis, respectively. As it concerns the surrounding regions the grid was kept fine close to the considered region, and changed gradually to coarse near the outer boundary. The expansion rate for the grid adjustment was kept lower than 1.2.

As it concerns the interference from the boundaries to the flow, the distance between the object and the boundaries of the domain was set equal to 6 times the characteristic length for the position of the inlet $(6 \mathrm{H}), 8$ times to the position of outlet $(8 \mathrm{H})$ and 5 times to the lateral boundaries $(5 \mathrm{H})$. The top and side boundaries were considered as the symmetry conditions.

The equations of the simulation are solved iteratively as a steady-state.

- Inlet boundary: $U(z)=U r(z / z r)=0.45, z r=1.5 \mathrm{~m}$ and $U r=1.0 \mathrm{~m} / \mathrm{s}$.

- Outlet boundary: zero gradient.

- Lateral boundaries: symmetry planes and zero gradients.

\section{Description of the initial state of the park - monitoring and simulation results}

Detailed measurements were performed in the park during the 14th and 15th of April, just before the start of the installation of the cool pavements. Both days were clear and solar radiation intensity during noon was close to $800 \mathrm{~W} / \mathrm{m}^{2}$. Daily average surface temperatures in the non-shaded parts of the park varied between $24.5^{\circ} \mathrm{C}$ for the grass, $26.7{ }^{\circ} \mathrm{C}$ for the pavements, $28.4{ }^{\circ} \mathrm{C}$ for the asphalt and $28.8^{\circ} \mathrm{C}$ for the dark bare soil. Corresponding surface temperatures in the shaded parts were measured to be $6-9 \mathrm{~K}$ lower.

Wind speed at $3.5 \mathrm{~m}$ height varied between $0.3 \mathrm{~m} / \mathrm{s}$ to $5.0 \mathrm{~m} / \mathrm{s}$ for both days. Higher values were measured close to the sea front and much lower in the interior of the park. In particular wind speeds next to the coast varied between 2.0 and $5.0 \mathrm{~m} / \mathrm{s}$ with an average value close $4.0 \mathrm{~m} / \mathrm{s}$, while in the inner part of the park, wind speed never exceeded $3 \mathrm{~m} / \mathrm{s}$ with an average value close to $1.5 \mathrm{~m} / \mathrm{s}$. Higher values were recorded during noon and the early afternoon period when the sea breeze was fully established.

Ambient temperatures varied for both days between $16.5^{\circ} \mathrm{C}$ and 19.8 at a height of $3.5 \mathrm{~m}$ for the period between 9:00 and 17:00. The spatial and temporal variation of the temperature in the park for the 

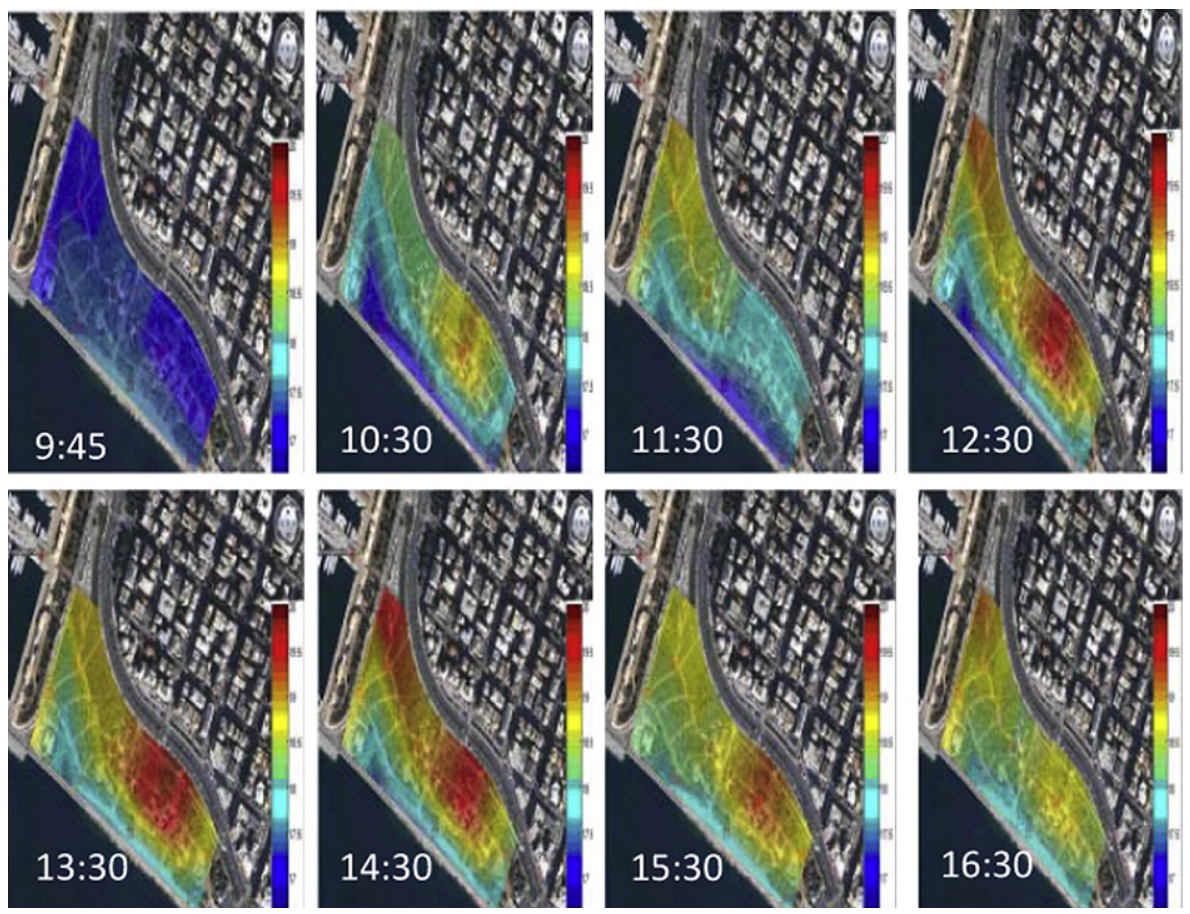

Fig. 5. Measured spatial distribution of the ambient temperature at $3.5 \mathrm{~m}$ height for the 15 th of April.

15th of April is shown in Fig. 5. Lower temperatures were always measured next to the sea front, while the maximum ones were recorded close to the existing constructions in the park and next to the highway. The maximum spatial temperature gradient in the park was close to $2.2 \mathrm{~K}$ and was recorded in the early afternoon period.

Following the specific evaluation methodology described previously, specific simulations were carried out, in order to predict the thermal conditions in the considered space during the period when the measurements were performed. In all simulations the undisturbed boundary conditions were taken by the National Observatory of Athens and were used as inputs to the CFD code. The surface temperature of the main materials in the area was simulated and then used as input to the model. The maximum difference between the measured and the predicted surface temperatures never exceeded $0.4 \mathrm{~K}$. Simulations were performed for many different measured boundary conditions and the model was continuously improved to better fit the existing conditions.

Fig. 6 presents the measured, as well as the predicted values of the ambient temperature at a height of $3.5 \mathrm{~m}$ for the 14:00 of the 15th of April. The undisturbed wind speed was $2 \mathrm{~m} / \mathrm{s}$ and the ambient temperature $19{ }^{\circ} \mathrm{C}$. As shown, the agreement between the theoretical and the measured temperatures is satisfactory. The maximum temperature difference between the two sets of data never exceeded $0.5 \mathrm{~K}$. The spatial distribution of the temperature is also similar for both the measured and the theoretical data. The lowest temperatures were predicted to be present next to the sea front while the maximum ones inside the park and close to the existing structures. Similar quality of results was obtained for the rest of the simulated cases. Thus, it may be concluded that the developed theoretical thermal model can, with sufficient accuracy, predict the climatic conditions in the area prior to the installation of the cool pavements.

\section{Application of the cool pavements - monitoring results}

After the installation of the cool pavements in the park, detailed measurements were performed, using exactly the same experimental protocol as in the first monitoring campaign. Measurements were performed for the 27th of July and the 4th of August. Both days were clear and solar radiation intensity during the noon period was 840 and $950 \mathrm{~W} / \mathrm{m}^{2}$ for the first and the second day respectively.

The daily surface temperature of the non-shaded cool pavements varied between $31.3{ }^{\circ} \mathrm{C}$ and $33.8{ }^{\circ} \mathrm{C}$ during the first day and $37.6{ }^{\circ} \mathrm{C}$ and $39.9{ }^{\circ} \mathrm{C}$ during the second one. The corresponding surface temperatures for the conventional pavement varied between $35.9{ }^{\circ} \mathrm{C}$ and $39.2{ }^{\circ} \mathrm{C}$ for the first day and $43.4{ }^{\circ} \mathrm{C}$ and $47.5^{\circ} \mathrm{C}$ for the second one. The maximum temperature difference between the cool and conventional pavements was $5.4 \mathrm{~K}$ and $7.6 \mathrm{~K}$ for the first and the second day respectively. Fig. 7, shows the surface temperature of the shaded (AR01), and non-shaded cool pavements

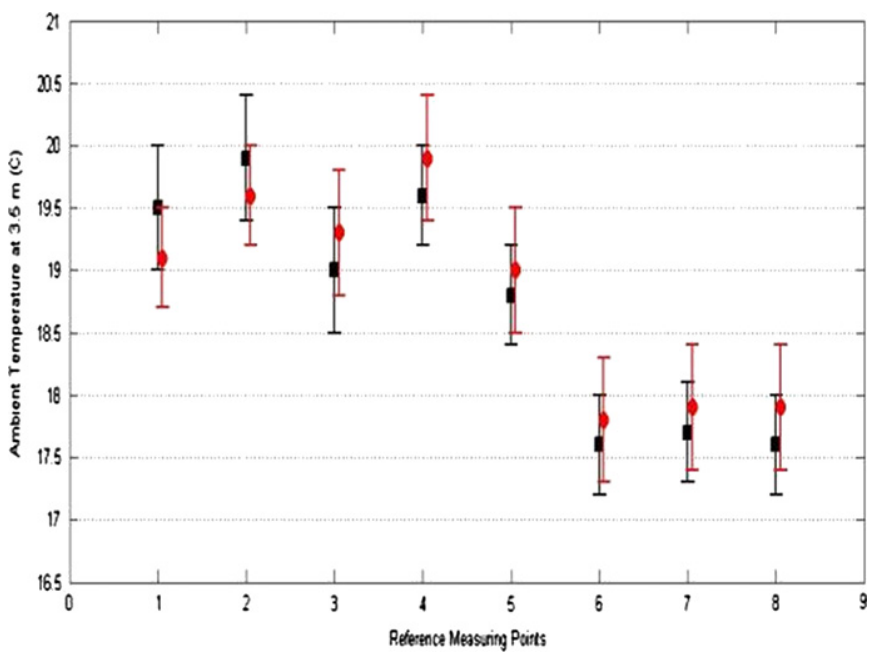

Fig. 6. Comparison of the measured temperatures, (black), at the eight reference points in the park against the predicted ones, (red), for the 15th of April. (For interpretation of the references to color in this figure legend, the reader is referred to the web version of this article.) 


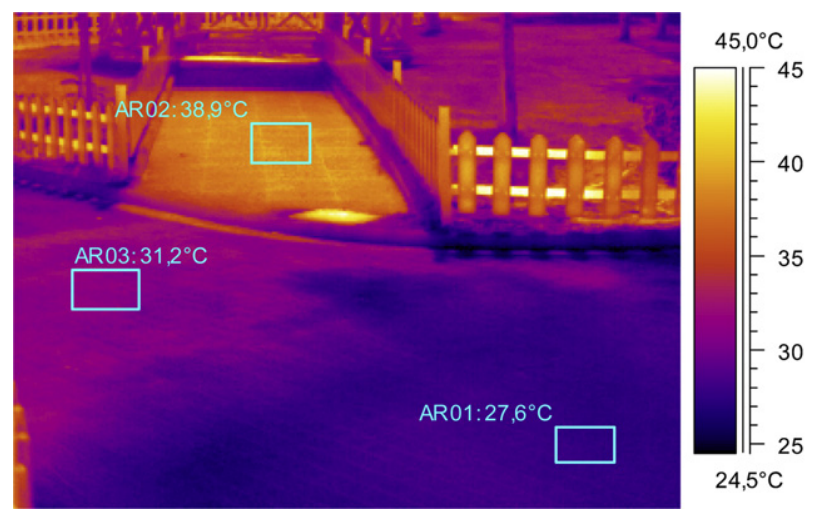

Fig. 7. Surface temperature of the Cool shaded, (AR01), the conventional non-shaded, (AR02), and the cool non-shaded pavement, (AR03).

(AR03), as well as the surface temperature of a remaining part of the previously used pavement (AR02). It should be mentioned that the conventional pavement was darker with an average solar reflectivity close to 0.48 while as previously mentioned the reflectivity of the cool pavement was close to 0.6.

Wind speed in the park and varied between 0.9 and $6.2 \mathrm{~m} / \mathrm{s}$ at $3.5 \mathrm{~m}$ height. As previously, higher values were recorded close to the coast where the average speed was around $4 \mathrm{~m} / \mathrm{s}$, while in the interior part of the park the average speed was close to $2.2 \mathrm{~m} / \mathrm{s}$.

The temporal variation of the ambient temperature at $3.5 \mathrm{~m}$ height, as measured in the 27th of July is given in Fig. 8. As expected, lower temperatures were measured next to the sea front, $\left(26^{\circ} \mathrm{C}-28.2^{\circ} \mathrm{C}\right.$ ), while temperatures in the interior part of the park varied between $26.5^{\circ} \mathrm{C}$ and $29.5^{\circ} \mathrm{C}$. The evolution of the temperature in the interior part of the park was not uniform during the day because of the strong winds from the sea affecting mainly the non protected southern part of the area. The maximum spatial temperature gradient in the park was close to $1.5 \mathrm{~K}$.

The same evaluation methodology as described previously was followed and CFD simulations were performed for the 27th of July.

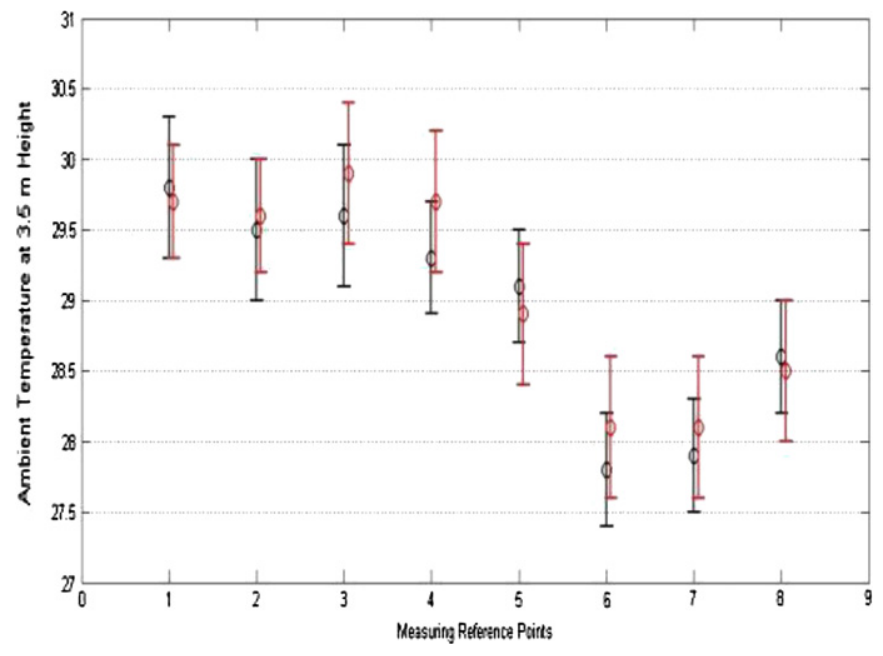

Fig. 9. Comparison of the measured temperatures, (black), at the eight reference points in the park against the predicted ones, (red) for the 27th of July. (For interpretation of the references to color in this figure legend, the reader is referred to the web version of this article.)

The undisturbed climatic conditions given by the National Observatory of Athens were used as inputs. Surface temperatures for all materials including the cool pavements was calculated using TRNSYS and then were used as inputs to the CFD model. A very good agreement between the calculated and the measured surface temperatures was achieved. The maximum difference between the measured and the simulated data never exceeded $0.3 \mathrm{C}$. Through repetitive runs the model was improved as much as possible in order to represent the new climatic situation in the park.

Fig. 9 gives the measured as well as the calculated values of the ambient temperature at $3.5 \mathrm{~m}$ height for the 14:00 of the 27th of July. The undisturbed wind speed was $2 \mathrm{~m} / \mathrm{s}$ and the ambient temperature $28^{\circ} \mathrm{C}$. The achieved agreement between the two sets of data is found quite satisfactory and the difference never
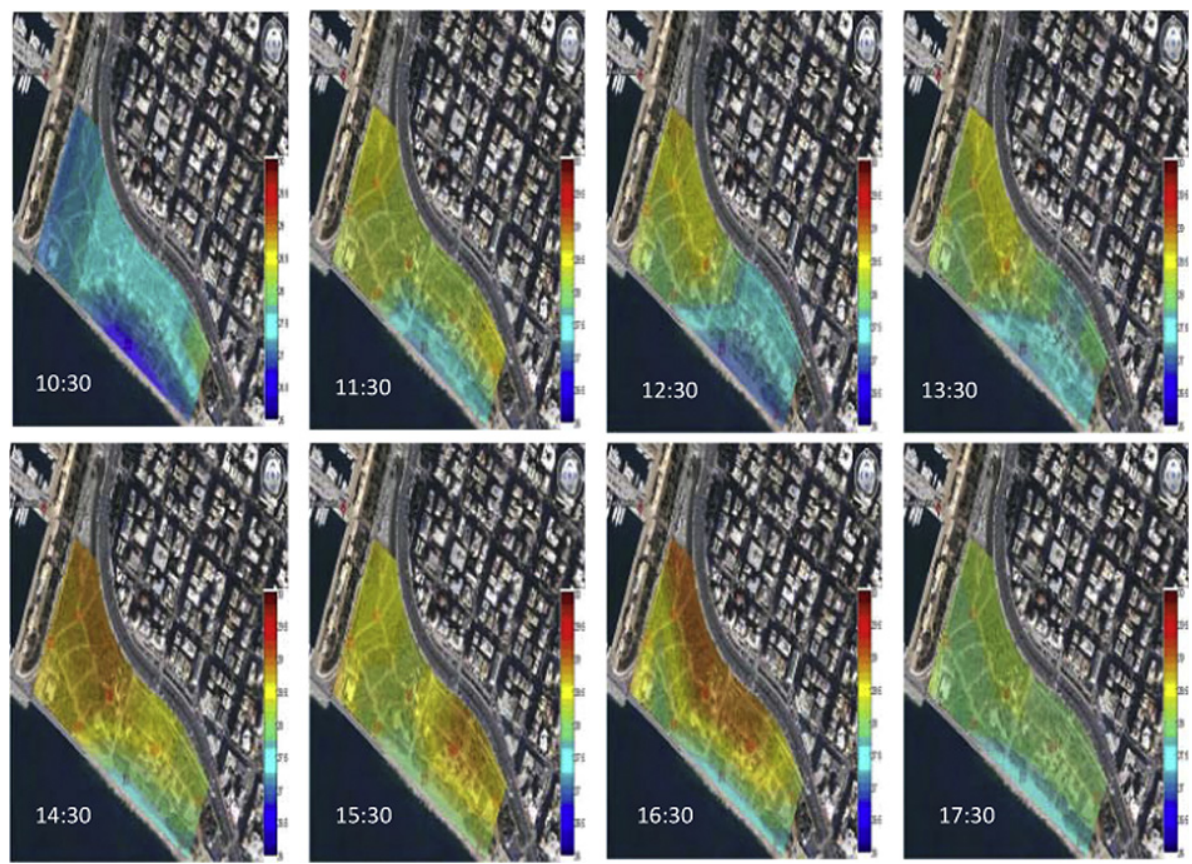

Fig. 8. Measured spatial distribution of the ambient temperature at $3.5 \mathrm{~m}$ height for the 4 th of August. 


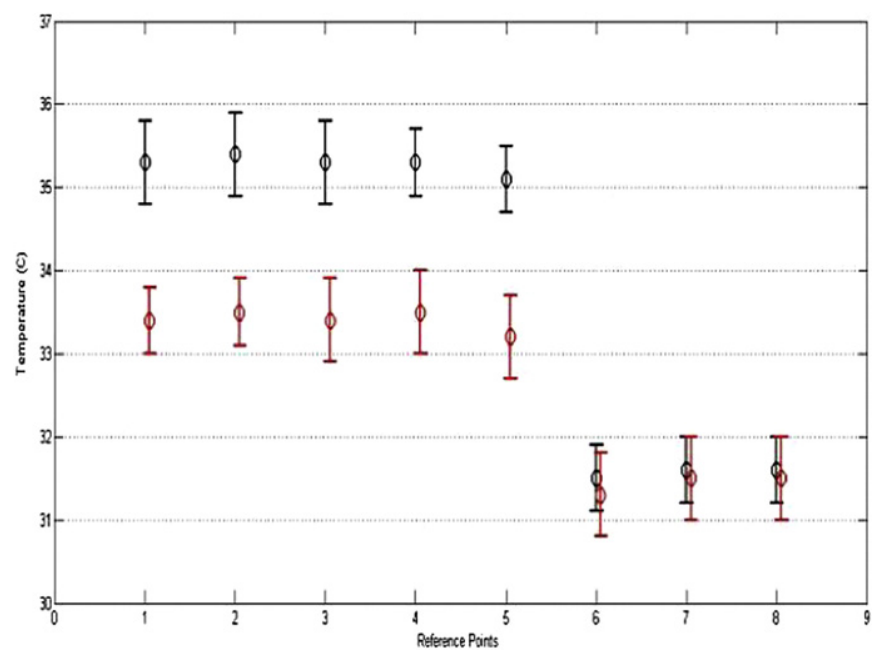

Fig. 10. Comparison of the predicted distribution of the ambient temperature in the park at $1.80 \mathrm{~m}$ height for 14:00 of a typical summer day before, (black), and after the installation of the cool pavements, (red). (For interpretation of the references to color in this figure legend, the reader is referred to the web version of this article.)

exceeded $0.4 \mathrm{~K}$. The predicted spatial distribution of the ambient temperature is very close to the measured one. It may be concluded that the developed thermal model to predict the climatic quality of the park when cool pavements are considered is of acceptable quality.

\section{Calculation of the microclimatic improvements}

As foreseen by the evaluation methodology, comparative simulations of the thermal conditions in the considered space were performed for the peak period, (14:00), of a typical summer day, with and without cool pavements. The developed and tested CFD models were used correspondingly.

The undisturbed temperature and wind speed used for the boundary conditions were $32{ }^{\circ} \mathrm{C}$ and $2 \mathrm{~m} / \mathrm{s}$ blowing from northern directions. The solar radiation intensity was taken equal to $940 \mathrm{~W} /$ $\mathrm{m}^{2}$. Surface temperatures for all materials were calculated using the TRNSYS thermal simulation model. The average temperature of the non-shaded cool pavement was calculated equal to $36.8^{\circ} \mathrm{C}$ while the temperature of the conventional pavement equal to $48.1^{\circ} \mathrm{C}$.

The calculated ambient temperatures for both scenarios at the eight reference points are given in Fig. 10, while in Fig. 11 the calculated spatial distributions of the temperature with and without the cool pavements are given. As expected, for the part of the park close to the sea, (points 6-8), temperatures are very similar and the impact of cool pavements is fully negligible. On the contrary, at the interior of the park the impact of cool pavements is important and contributes to a decrease of the maximum ambient temperature up to $1.9 \mathrm{~K}$. This is very close to the results reported in similar projects were cool pavements have been considered to improve the environmental quality of open spaces [42,43].

Improvement of the thermal comfort conditions of outdoor spaces is the main goal of every bioclimatic design. Evaluation of the thermal comfort levels may be performed using various thermal comfort indices [48-50]. The results of the performed simulations have been used to evaluate thermal comfort conditions in the considered park. The CP, Cooling Power comfort index was used [51],

$$
\mathrm{CP}=(0.421+0.087 \times v) \times(36.5-t) \quad\left(\mathrm{mcal} \mathrm{cm}^{-2} / \mathrm{s}\right)
$$

where $t$ is the mean ambient temperature $\left({ }^{\circ} \mathrm{C}\right) ; v$ is the wind speed $(\mathrm{m} / \mathrm{s})$.

Different values of the $\mathrm{CP}$ comfort index correspond to various comfort conditions as shown in Table 1. Calculations of the thermal comfort index $\mathrm{CP}$ were performed for the eight reference points using the results of the CFD calculations, carried out for the typical summer a

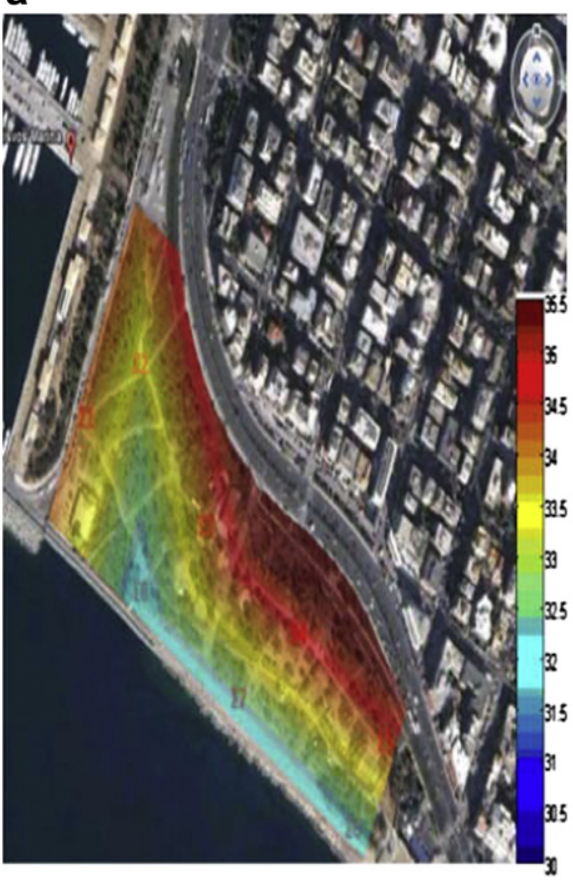

Without the CoolPavement b

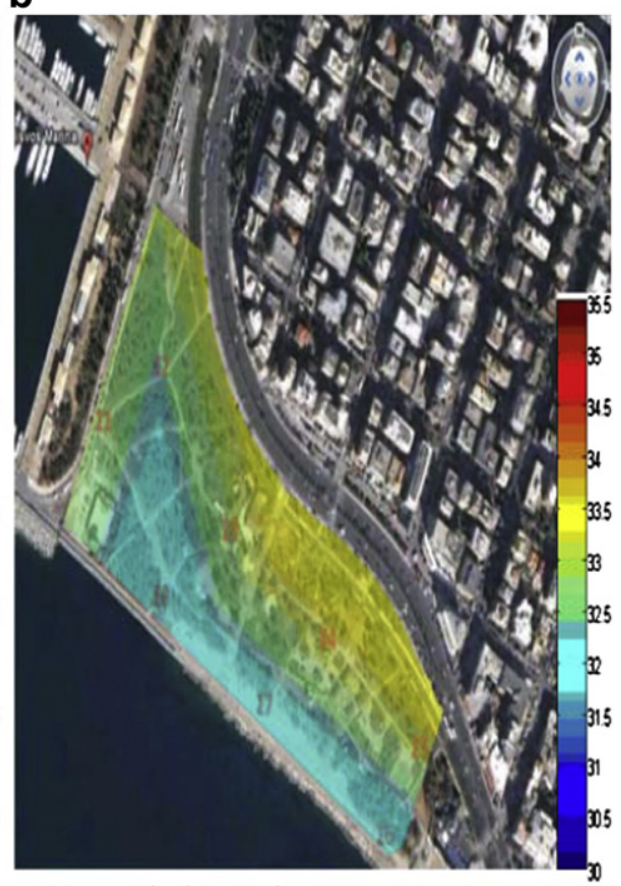

With the Cool Pavement

Fig. 11. Spatial distribution of the ambient temperature in the park during a typical summer day, (a) without the cool pavements, and (b) With the cool pavements. 
Table 1

Comfort conditions corresponding to different values of $\mathrm{CP}$.

\begin{tabular}{lll}
\hline & CP Value mcal cm $\mathrm{cm}^{-1}$ & Comfort Conditions \\
\hline 1 & $<0.6$ & Extremely Hot \\
2 & $0.6-2.6$ & Very Hot \\
3 & $2.7-5.1$ & Quite Hot \\
4 & $5.2-6.4$ & Warm \\
5 & $6.5-8.0$ & Comfortable \\
6 & $8.1-10.4$ & Acceptable Cool \\
7 & $10.5-15.4$ & Cold \\
8 & $15.6-22.4$ & Very Cold \\
9 & $22.6-30.0$ & Extremely Cold \\
10 & $>30.0$ & Glacial \\
\hline
\end{tabular}

day and for the conditions occurring before and after the installation of the cool pavements. The obtained results are given in Fig. 12.

As shown, comfort conditions in the park before the installation of the cool pavement and under unfavorable climatic conditions were almost at the zone of 'Extremely Hot' except from the area close to the coast. When, the cool pavements are considered, comfort conditions were significantly improved and are in the zone of 'Very Hot' and close to the 'Quite Hot' zone. This is also empirically verified as the number of visitors in the area has been tremendously increased while most of the visitors expressed satisfaction about the thermal conditions in the area.

The reported results are valid inside the limits of the climatic boundary conditions of the present study. For lower levels of solar radiation and ambient temperature the contribution of cool paving materials is expected to decrease. Also, under much higher wind speeds advection phenomena may be dominant and the contribution of the local convection and radiation phenomena may be limited.

The exact climatic zones where cool materials can be recommended may be determined after specific experimental and theoretical research. However, experimental results collected through the Cool Roofs Project of the European Commission [52], have shown that the use of cool materials contribute in a positive way to buildings located up to the latitude of London, UK.

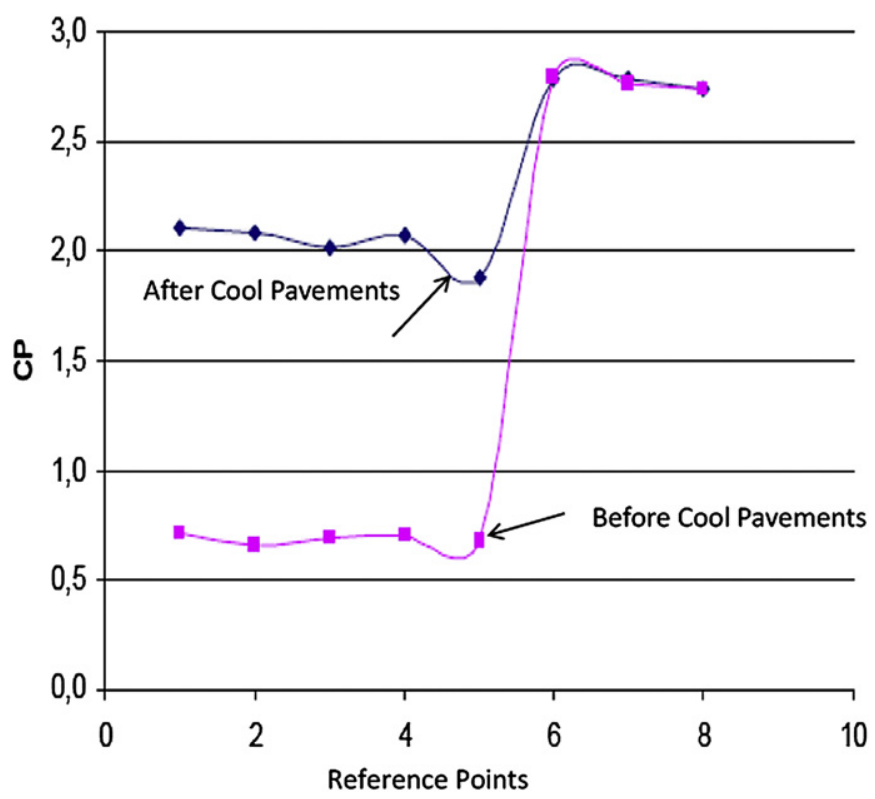

Fig. 12. Calculated values of the thermal comfort index $\mathrm{CP}$ at the eight reference points in the park before and after the installation of the cool pavements. Calculations are carried out for a typical summer day, (14:00).
As it concerns the impact of cool paving materials on the winter climatic conditions in the park, previous research has shown that under cloudy conditions the surface temperature of the cool paving materials is very similar to the temperature of conventional materials, whilst for the mid seasons the surface temperature drop was almost negligible [43].

\section{Conclusions}

Heat island increases temperature in urban areas, increases the energy consumption for cooling purposes and affects the global environmental quality of cities. The use of advanced mitigation techniques highly contributes to decrease temperatures and improve comfort in open urban areas. Cool materials presenting a high solar reflectivity and emissivity have been proposed as an effective mitigation technique when applied to buildings and open spaces. Although many experimental data are available to evaluate the performance of cool materials in isolated buildings, very limited information is available concerning the mitigation potential of the reflective materials when applied in open urban areas.

Almost $4500 \mathrm{~m}^{2}$ of cool pavements were used to rehabilitate a major urban park in the greater Athens area. To our knowledge, it is the largest application of cool pavements in open spaces. In order to evaluate the impact of cool pavements, measurements of the climatic conditions in the considered were performed before and after the installation of the cool materials. Given that climatic boundary conditions differ considerably during the two monitoring campaigns, a direct comparison of the collected data sets is not possible.

To overcome the problem, an evaluation methodology has been designed and applied. Computerized fluid dynamic techniques were used to simulate the specific climatic conditions in the area before and after the installation of the new pavements. After validation against the two sets of the collected experimental data, comparative calculations were performed with and without the cool pavements under the same climatic boundary conditions. It was found that the extensive application of reflective pavements, under the specific climatic conditions, may reduce the peak daily ambient temperature during a typical summer day up to $1.9 \mathrm{~K}$ while surface temperatures were reduced up to $12 \mathrm{C}$. In parallel, calculations of the thermal comfort conditions in the area have shown that cool pavements considerably improve comfort in outdoor urban spaces. The specific results may change as a function of the climatic conditions prevailing in the area where cool pavements are applied. In particular, under strong wind conditions, advection phenomena may dominate and the impact of local convection and radiation phenomena will be lowered. Also, for lower levels of the ambient temperature and solar radiation the summer contribution of cool paving materials is expected to be reduced. Finally, the use of cool paving materials is not expected to decrease the local ambient temperature during the winter period.

The overall analysis has shown that the use of cool pavements is an efficient mitigation strategy in order to reduce the intensity of heat island in urban areas and improve the global environmental quality of open areas.

\section{References}

[1] Santamouris M, editor. Energy and climate in the urban built environment. James and James (Science); 2001.

[2] Santamouris M. Heat island research in Europe - state of the art. Adv Build Energ Res 2007;1:123-50.

[3] Akbari H, Davis S, Dorsano S, Huang J, Winert S. Cooling our communities-a guidebook on tree planting and white coloured surfacing. US Environmental Protection Agency, Office of Policy Analysis, Climate Change Division; 1992.

[4] Cartalis C, Synodinou A, Proedrou M, Tsangrassoulis A, Santamouris M. Modifications in energy demand in urban areas as a result of climate changes: 
an assessment for the southeast Mediterranean region. J Energ Convers Manag 2001;42(14):1647-56.

[5] Founda D. Evolution of the air temperature in Athens and evidence of climatic change: a review. J Adv Build Energ Res 2011;5(1):7-41,.

[6] Asimakopoulos D, Santamouris M, Farrou I, Laskari M, Saliari M, Zanis G. Modelling the energy demand projection of the building sector in Greece in the 21st century, submitted for publication.

[7] Livada I, Santamouris M, Assimakopoulos MN. On the variability of summer air temperature during the last 28 years in Athens, JGR, 2007. J Geophys Res 2007;112:D12103.

[8] Mihalakakou G, Flocas HA, Santamouris M, Helmis CG. Application of neural networks to the simulation of the heat island over Athens, Greece, using synoptic types as a predictor. J Appl Meteorol 2002;41:5519-27.

[9] Gobakis K, Kolokotsa D, Synnefa A, Saliari M, Giannopoulou K, Santamouris M. Development of a model for urban heat island prediction using neural network techniques. Sustain Cities Soc 2011;1(2):104-15.

[10] Mihalakakou G, Santamouris M, Papanikolaou N, Cartalis C, Tsangrassoulis A. Simulation of the urban heat island phenomenon in Mediterranean climates. J Pure Appl Geophys 2004;161:429-51.

[11] Livada I, Santamouris M, Niachou K, Papanikolaou N, Mihalakakou G. Determination of places in the great Athens area where the heat island effect is observed. Theor Appl Climatol 2002;71:219-30.

[12] Pantavou K, Theoharatos G, Mavrakis A, Santamouris M. Evaluating thermal comfort conditions and health responses during an extremely hot summer in Athens. Build Environ 2011;46.

[13] Hassid S, Santamouris M, Papanikolaou N, Linardi A, Klitsikas N, Georgakis C et al. The effect of the Athens heat island on air conditioning load. J Energ Build 2000;32:2131-41

[14] Santamouris M, Papanikolaou N, Livada I, Koronakis I, Georgakis C, Argiriou A, et al. On the impact of urban climate to the energy consumption of buildings. Sol Energy 2001;70:3201-16.

[15] Stathopoulou E, Mihalakakou G, Santamouris M, Bagiorgas HS. Impact of temperature on tropospheric ozone concentration levels in urban environments. J Earth Syst Sci 2008;117(3):227-36.

[16] Santamouris M, Paraponiaris K, Mihalakakou G. Estimating the ecological footprint of the heat island effect over Athens, Greece. Clim Change 2007;80: 265-76.

[17] Santamouris M, Pavlou K, Synnefa A, Niachou K, Kolokotsa D. Récent progress on passive cooling techniques. advanced technological developments to improve survivability LEVELS in low - income households. Energ Build 2007;39:859-66.

[18] Doulos L, Santamouris M, Livada I. Passive Cooling of outdoor urban spaces. The role of materials. Sol Energy 2004;77(2):231-49.

[19] Zinzi M. Cool materials and cool roofs: Potentialities in Mediterranean buildings. Adv Build Energ Res 2010;4(1):201-66.

[20] Yu Chen, Hien, Wong Nyuk. Thermal impact of strategic landscaping in cities: a review. Adv Build Energ Res 2009;3(1):237-60.

[21] Julia E, Santamouris M, Dimoudi A. Monitoring the effect of urban green areas on the heat island in Athens. Environ Monit Assess 2009;156(1-4):275-292,

[22] Theodosiou Theodore. Green roofs in buildings: thermal and environmental behaviour. Adv Build Energ Res 2009;3(1):271-88.

[23] Niachou, Papakonstantinou K, Santamouris M, Tsangrassoulis A Mihalakakou G. Analysis of the green roof thermal properties and investigation of its energy performance. J Energ Build 2001;33:719-29.

[24] Santamouris M, Pavlou C, Doukas P, Mihalakakou G, Synnefa A, Hatzibiros A et al. Investigating and analysing the energy and environmental performance of an experimental green roof system installed in a nursery school building in Athens, Greece. Energy 2007;32(9):1781-8.

[25] Sfakianaki E, Pagalou K, Pavlou M, Santamouris Assimakopoulos MN. Theoretical and experimental analysis of the thermal behaviour of a green roof system installed in two residential buildings in Athens, Greece. Int J Energ Res 2009;33(12):1059-69.

[26] Mihalakakou G, Santamouris M, Asimakopoulos D. On the use of ground for heat dissipation. J Energy 1994;19(1):17-25.

[27] Tzaferis A, Liparakis D, Santamouris M, Argiriou A. Analysis of the accuracy and sensitivity of eight models to predict the performance of earth to air heat exchangers. J Energ Build 1992;18:35-43.

[28] Santamouris M, Synnefa A, Karlessi T. Using advanced cool materials in the urban Built environment to mitigate heat islands and improve thermal comfort conditions. Sol Energy 2011;85:3085-102.
[29] Zinzi M, Carlo Romeo. Impact of a cool roof application on the energy and comfort performance in an existing non-residential building. A Sicilian case study, Energ Build, in press.

[30] Synnefa A, Saliari M, Santamouris M. Experimental and numerical assessment of the impact of increased roof reflectance on a school building in Athens, Energ Build, in press.

[31] Synnefa, Dandou A, Santamouris M, Tombrou M, Soulakellis N. Use of cool materials as a heat island mitigation strategy. J Appl Meteorol Climatol 2008 47(11):2846-56. J Appl Met.

[32] Akbari H, Menon S, Rosenfeld A. Global cooling: increasing world-wide urban albedos to offset $\mathrm{CO}_{2}$. Climatic Change 2009;94(3-4):275-86.

[33] Santamouris M, Synnefa A, Kolokotsa D, Dimitriou V, Apostolakis K. Passive cooling of the built environment - use of innovative reflective materials to fight heat island and decrease cooling Needs. Int J Low Carbon Tech 2009;3(2): 71-82.

[34] Synnefa A, Santamouris M, Akbari H. Estimating the effect of using cool coatings on energy loads and thermal comfort in residential buildings in various climatic conditions. Energ Build 2007;39(11):1167-74.

[35] Synnefa M, Santamouris I, Livada. A study of the thermal performance of reflective coatings for the urban environment. Sol Energy 2006;80(8):968-81.

[36] Synnefa A, Santamouris M, Apostolakis K. On the development, optical properties and thermal performance of cool colored coatings for the urban environment. Sol Energy 2007;81:488-97.

[37] Levinson R, Akbari H, Reilly JC. Cooler tile-roofed buildings with nearinfrared-reflective non-white coatings. Build Environ 2007;42(7):2591-605.

[38] Synnefa A, Karlessi T, Gaitani N, Santamouris M, Assimakopoulos DN Papakatsikas C. On the optical and thermal performance of cool colored thin layer asphalt used to improve urban microclimate and reduce the energy consumption of buildings. Build Environ 2011;46(1):38-44.

39] Levinson R, Akbari H, Berdahl P, Wood K, Skilton W, Petersheim. A nove technique for the production of cool colored concrete tile and asphalt shingle roofing products. Sol Energ Mat Sol C 2010;94(6):946-54.

[40] Karlessi T, Santamouris M, Apostolakis K, Synnefa A, Livada I. Development and testing of thermochromic coatings for buildings and urban structures. Sol Energy 2009;83(4):538-51.

[41] Karlessi T, Santamouris M, Synnefa A, Assimakopoulos D, Didaskalopoulos P, Apostolakis K. Development and testing of PCM doped cool colored coatings to mitigate urban heat island and cool buildings. Build Environ 2011;46(3): 570-6.

[42] Fintikakis N, Gaitani N, Santamouris M, Assimakopoulos M Assimakopoulos DN, Fintikaki M, et al. Bioclimatic design of open public spaces in the historic centre of Tirana, Albania. Sustain Cities Soc 2011;1(1):54-62.

[43] Gaitani N, Spanou A, Saliari M, Synnefa A, Vassilakopoulou K, Papadopoulou K, et al. Improving the microclimate in urban areas. A case study in the centre of Athens. J Build Serv Eng 2011;32(1):53-71.

[44] Giannopoulou K, Livada I, Santamouris M, Saliari M, Assimakopoulos M Caouris YG. On the characteristics of the summer urban heat island in Athens, Greece. J Sustain Cities Soc 2011;1(1):16-28.

[45] Georgakis C, Santamouris M. Experimental investigation of air flow and temperature distribution in deep urban canyons for natural ventilation purposes. Energ Build 2006;38(4):367-76.

[46] PHOENICS software tool. Available at: http://www.cham.co.uk/.

[47] TRNSYS software tool. Available at: http://www.trnsys.de.

[48] Tselepidaki I, Santamouris M, Moustris C, Poulopoulou G. Analysis of the summer discomfort index in Athens, Greece, for cooling purposes. Energ Build 1992;18:51-6.

[49] Tsinonis A, Koutsogiannakis I, Santamouris M, Tselepidaki I. Statistical analysis of summer comfort conditions in Athens, Greece. Energ Build 1993;19: 285-90.

[50] Balaras C, Tselepidaki I, Santamouris M, Asimakopoulos D. Calculations and statistical analysis of the environmental cooling power index for Athens, Greece. J Energ Convers Manag 1993;34(2):139-46.

[51] Cena M, Gregorczuck M, Wojcik G. Proba Wyznaczenia wzoru do obliczania ochladzania biometeorologiczenero warunkach klimatycznych Polski [An attempt to determine through formulae computation of biometeorological cooling power in Poland]. Roczniki Nauk Rolniczych; 1966:137-48.

[52] Synnefa A, Santamouris M. Advances on technical, policy and market aspects of cool roofs technology in Europe: the cool roofs project. Energ Build; 2010 doi:10.1016/j.enbuild.2011.11.051. 